\title{
Aktivitas Antibakteri Ekstrak Air Kopi Robusta (Coffea canephora) terhadap Bakteri Pseudomonas Aeruginosa
}

\author{
Naura Mufida Marsya*, Hendro Sudjono Yuwono \\ Prodi Pendidikan Dokter, Fakultas Kedokteran, Universitas Islam Bandung, \\ Indonesia. \\ *marsya.naura@gmail.com, hsyabc47@gmail.com
}

\begin{abstract}
Pseudomonas aeruginosa is common in Healthcare-Associated Infections (HAIs) and shows resistance to many common antimicrobial agents. Robusta coffee has been chosen as an alternative to antibiotics because of its antibacterial properties. This study aims to determine the antibacterial activity of Robusta coffee (Coffea canephora) water extract against Pseudomonas aeruginosa. The treatments given was agar plate that added Robusta coffee water extract in 4 doses, namely $12.5 \%, 25 \%, 50 \%$, and $100 \%$, imipenem antibiotic disc (positive control), and disk containing aquadest (negative control). They were then incubated in an incubator at $37^{\circ} \mathrm{C}$ for 24 hours. The assessment was carried out by observing and measuring the inhibition zone. The research data proved that the inhibition zone produced by robusta coffee water extract at a dose of $100 \%$ had the highest average compared to other doses, which is at $8.13 \mathrm{~mm}$, but smaller than imipenem which had an average inhibition zone of $25 \mathrm{~mm}$. This shows that robusta coffee water extract has an antibacterial effect against Pseudomonas aeruginosa.
\end{abstract}

Keywords: Antibacterial, Imipenem, Pseudomonas aeruginosa, Robusta Coffee.

\begin{abstract}
Abstrak. Pseudomonas aeruginosa umum ditemukan pada Healthcare-Associated Infections (HAIs) dan menunjukkan resistensi pada banyak agen antimikroba yang umum. Kopi Robusta telah dipilih sebagai antibiotik alternatif karena memiliki kemampuan antibakteri. Penelitian ini bertujuan untuk mengetahui aktivitas antibakteri ekstrak air kopi robusta (Coffea canephora) terhadap bakteri Pseudomonas aeruginosa. Perlakuan yang diberikan adalah media agar diberi disk yang mengandung ekstrak air kopi robusta dalam 4 dosis yaitu $12,5 \%, 25 \%, 50 \%$, dan $100 \%$, imipenem (kontrol positif), dan disk yang mengandung aquadest (kontrol negatif). Agar diinkubasi dalam inkubator dengan suhu $37^{\circ} \mathrm{C}$ selama 24 jam. Penilaian dilakukan dengan pengamatan dan pengukuran zona inhibisi. Data hasil penelitian membuktikan zona inhibisi yang dihasilkan oleh ekstrak air kopi robusta pada dosis 100\% memiliki rata-rata paling tinggi dibandingkan dengan dosis lainnya yaitu $8,13 \mathrm{~mm}$, namun lebih kecil dibandingkan dengan imipenem yang memiliki rata-rata zona inhibisi sebesar $25 \mathrm{~mm}$. Hal ini menunjukkan bahwa ekstrak air kopi robusta memiliki efek antibakteri terhadap Pseudomonas aeruginosa.
\end{abstract}

Kata Kunci: Antibakteri, Imipenem, Kopi Robusta, Pseudomonas aeruginosa. 


\section{A. Pendahuluan}

Prevalensi HAIs di Asia Tenggara lebih tinggi dibandingkan di Eropa dan Pasifik Barat. Pseudomonas aeruginosa merupakan salah satu bakteri paling umum yang ditemukan pada Healthcare-Associated Infections (HAIs). P.aeruginosa memiliki plastisitas genetik yang luar biasa sehingga mudah beradaptasi dengan berbagai perawatan dari fasilitas pelayanan kesehatan dan menunjukkan resistensi pada banyak agen antimikroba yang umum. Resistensi antibiotik menyebabkan keberhasilan pengobatan terhadap infeksi P. aeruginosa menjadi sangat terbatas, karbapenem dan imipenem sering dipandang sebagai terapi terakhir untuk bakteri MDR Gramnegatif termasuk P.aeruginosa. Organisasi Kesehatan Dunia baru-baru ini mendaftarkan P. aeruginosa yang resisten terhadap karbapenem sebagai salah satu dari tiga spesies bakteri di mana terdapat kebutuhan kritis untuk pengembangan antibiotik baru untuk mengobati infeksi.

Kopi berpotensi untuk digunakan sebagai agen antibakteri alami karena mengandung trigonelin, kafein, asam caffeic, serta asam klorogenat yang memiliki aktivitas antibakteri. Berdasarkan hal tersebut, penulis tertarik untuk meneliti aktivitas antibakteri ekstrak air kopi robusta terhadap bakteri Pseudomonas aeruginosa menggunakan metode disc diffusion (cakram disk). Penelitian ini bertujuan untuk Untuk mengetahui perbandingan besar daya hambat ekstrak air kopi robusta terhadap Pseudomonas aeruginosa.

\section{B. Landasan Teori}

Pseudomonas aeruginosa mudah beradaptasi dan memiliki kemampuan bertahan yang tinggi sehingga dapat bertahan pada permukaan benda mati di lingkungan rumah sakit yang kering dari 6 jam hingga 6 bulan dan sering mencemari peralatan kesehatan seperti, monitor, tombol ventilator, bedrail, peralatan pernapasan, tabung dialysis. P. aeruginosa juga dapat dibiakkan dari krim tangan, dan larutan pembersih tertentu dan juga dapat bertahan dalam beberapa solusi antiseptik yang digunakan untuk mendisinfeksi endoskopi dan instrumen bedah. Oleh karena itu, P. aeruginosa merupakan salah satu bakteri paling umum yang ditemukan pada HealthcareAssociated Infections (HAIs).

Terapi antibiotik empiris untuk kasus yang diduga P. aeruginosa adalah monoterapi dan terapi kombinasi, terapi ini mengurangi kematian pada pasien dengan infeksi $\mathrm{P}$. aeruginosa yang parah. Namun, pengobatan infeksi P. aeruginosa telah menjadi tantangan besar karena kemampuan bakteri ini untuk melawan banyak antibiotik yang tersedia saat ini. Selain itu, penggunaan antibiotik yang berlebihan selama pengobatan mempercepat pengembangan strain P. aeruginosa yang resisten terhadap multi-obat, yang menyebabkan tidak efektifnya terapi antibiotik empiris terhadap mikroorganisme ini.

P. aeruginosa menunjukkan resistensi intrinsik terhadap beberapa antibiotik beta-laktam dan dapat memperoleh mekanisme resistensi tambahan karena peristiwa mutasi atau perolehan elemen genetik yang dapat ditransfer. Secara intrinsik, P. aeruginosa mengekspresikan AmpC beta-lactamase dan beberapa sistem pompa efluks yang mengekspor antibiotik. Organisasi Kesehatan Dunia (WHO) baru-baru ini mendaftarkan P. aeruginosa yang resisten terhadap karbapenem sebagai salah satu dari tiga spesies bakteri di mana terdapat kebutuhan kritis untuk pengembangan antibiotik baru untuk mengobati infeksi.

Karbapenem adalah agen antimikroba yang paling efektif melawan bakteri gram positif dan gram negatif termasuk P. aeruginosa. Karbapenem mengandung penemik bersamaan dengan cincin beta-laktam dan, seperti semua beta-laktam lainnya, mereka menghambat sintesis dinding sel bakteri dengan mengikat dan menonaktifkan Penicillin Binding Proteins (PBPs). Layaknya semua antibiotik $\beta$-laktam, karbapenem dapat tidak aktif terhadap bakteri melalui empat mekanisme resistensi: produksi enzim penghidrolisis karbapenem, lesi porin protein impermeabel, pengeluaran aktif molekul obat dari sel bakteri dengan pompa efluks, dan pemanfaatan carbapenem-insensitive transpeptidases. Penurunan aktivitas karbapenem meningkat ketika patogen memiliki lebih dari satu mekanisme ini. Selain itu, bakteri Gramnegatif resisten karbapenem hampir selalu memiliki mekanisme resistensi lain terhadap kelas antibiotik lainnya, termasuk aminoglikosida, fluoroquinolon, dan kotrimoksazol, yang secara drastis membatasi pilihan pengobatan. 
Kopi mengandung berbagai macam senyawa yang memiliki aktivitas antimikroba, seperti campuran kompleks senyawa fenolik. Mekanisme kerja antimikroba senyawa fenolik sangatlah kompleks. Mereka dapat mengerahkan aktivitas antimikroba mereka dengan mengubah struktur membran sitoplasma, mengganggu gaya motif proton, aliran elektron dan / atau transpor aktif. Juga, mekanisme toksisitas fenolik dapat mencakup penghambatan oleh senyawa teroksidasi, mungkin melalui reaksi dengan kelompok sulfhidril atau melalui interaksi yang lebih spesifik dengan protein. Oleh karena itu, aktivitas antimikroba kopi tidak disebabkan oleh satu mekanisme spesifik dan mungkin mengarah pada beberapa target dalam sel. Senyawa fenolik utama yang terdapat dalam ekstrak kopi dan paling sensitif terhadap P. aeruginosa adalah caffeic acid. Selain itu, dalam konsentrasi yang lebih besar asam klorogenik juga memiliki daya inhibisi terhadap P. aeruginosa.

\section{Pembahasan dan Diskusi}

Penelitian ini menggunakan kontrol negatif berupa disc yang mengandung aquadest, kontrol positif berupa disc antibiotik imipenem dan perlakuan berupa disc yang mengandung ekstrak air kopi robusta dalam empat konsentrasi yaitu 100\%, 50\%, 25\%, dan 12,5\%. Penelitian ini merupakan penelitian yang menguji aktivitas antibakteri ekstrak air kopi robusta terhadap pertumbuhan bakteri Pseudomonas aeruginosa. Aktivitas antibakteri dinilai dengan mengukur diameter zona inhibisi pada setiap perlakuan dan kontrol.

Tabel 1. Diameter Zona Inhibisi yang Terbentuk pada P. aeruginosa

\begin{tabular}{ccccccc}
\hline \multicolumn{7}{c}{ Diameter Zona Inhibisi (mm) } \\
\hline & $100 \%$ & $50 \%$ & $25 \%$ & $12,5 \%$ & Kontrol & Kontrol \\
& + & Ekstrak Air Kopi Robusta & - \\
\hline Rata-Rata & 8,13 & 6,88 & ND & ND & 25 & 0 \\
\hline
\end{tabular}

Keterangan ND $=$ Not Detected

Hasil penelitian diukur menggunakan penggaris dalam satuan millimeter dengan diameter disk adalah $6 \mathrm{~mm}$. Berdasarkan tabel tersebut dapat dilihat bahwa zona inhibisi pada perlakuan dengan esktrak air kopi robusta hanya terjadi pada dosis $100 \%$ dan $50 \%$. Sementara pada dosis $25 \%$ dan $12.5 \%$ tidak terdapat zona inhibisi sama sekali. Zona inhibisi yang juga tidak terbentuk pada kontrol negatif menandakan bahwa aquadest tidak memiliki aktivitas antibakteri terhadap Pseudomonas aeruginosa. Nilai rata-rata zona inhibisi pada kelompok yang diberikan ekstrak air kopi robusta dosis $100 \%$ adalah sebesar $8.13 \mathrm{~mm}$, sedangkan pada dosis $50 \%$ zona hambatnya memiliki rata-rata sebesar $6.88 \mathrm{~mm}$. Pada kontrol postif yaitu imipenem terbentuk zona inhibisi sebesar $25 \mathrm{~mm}$. Terbentuknya zona inhibisi di sekitar disk menandakan adanya aktivitas antibakteri terhadap Pseudomonas aeruginosa.

Meskipun sangat lemah dibandingkan dengan imipenem, ekstrak air kopi robusta tetap dibuktikan memiliki daya hambat terhadap Pseudomonas aeruginosa. Hal ini dikarenakan kopi mengandung berbagai macam senyawa yang memiliki aktivitas antimikroba, seperti campuran kompleks senyawa fenolik. Mekanisme kerja antimikroba senyawa fenolik sangatlah kompleks. Mereka dapat mengerahkan aktivitas antimikroba mereka dengan mengubah struktur membran sitoplasma, mengganggu gaya motif proton, aliran elektron dan / atau transpor aktif. Oleh karena itu, aktivitas antimikroba kopi tidak disebabkan oleh satu mekanisme spesifik dan mungkin mengarah pada beberapa target dalam sel. Senyawa fenolik utama yang terdapat dalam ekstrak kopi dan paling sensitif terhadap P. aeruginosa adalah asam caffeic. Selain itu, dalam konsentrasi yang lebih besar asam klorogenat juga memiliki daya inhibisi terhadap P. aeruginosa. Selain itu, kafein dan trigonelin adalah salah satu komponen terbesar dari senyawa alkaloid yang ditemukan dalam biji kopi yang berfungsi sebagai antibakteri. Menurut sebuah penelitian yang dilakukan oleh Almeida et al., kandungan trigonelline, kafein, dan asam klorogenat memiliki aktivitas antimikroba yang serupa.

Perbedaan diameter zona hambat pada setiap konsentrasi dapat disebabkan oleh perbedaan zat aktif yang terkandung dalam ekstrak air kopi Robusta yang bersifat antibakteri, seperti kafein, trigonelin, asam caffeic, dan asam klorogenat. Artinya semakin besar 
konsentrasinya maka semakin besar pula komponen zat aktif yang dikandungnya, akibatnya zona hambat yang terbentuk juga berbeda pada setiap konsentrasinya.

Selain itu, menurut Butler et al., Peningkatan dan penurunan zona hambat dapat disebabkan oleh komponen zat yang terkandung dalam tanaman kopi yang dapat saling melemahkan, memperkuat, memperbaiki, atau mengubah secara total efek tanaman kopi tersebut. Kualitas dan kuantitas zat yang terkandung dalam tanaman kopi ditentukan oleh faktor lingkungan, seperti iklim tumbuh, tanah, sinar matahari, dan kondisi pertumbuhan tanaman hingga saat panen.

\section{Kesimpulan}

Ekstrak air kopi robusta memiliki aktivitas antibakteri terhadap Pseudomonas aeruginosa yang ditandai dengan terbentuknya zona hambat pada kultur bakteri P.aeruginosa, namun zona hambatnya lebih kecil dibandingkan dengan antibiotik imipenem.

\section{Daftar Pustaka}

[1] Hapsari AP, Wahyuni CU, Mudjianto D. Knowledge of Surveillance Officers on Identification of Healthcare-associated Infections in Surabaya. J Berk Epidemiol. 2018 Aug 30;6(2):130.

[2] Ling ML, Apisarnthanarak A, Madriaga G. The burden of healthcare-associated infections in southeast Asia: A systematic literature review and meta-analysis. Vol. 60, Clinical Infectious Diseases. Oxford University Press; 2015. p. 1690-9.

[3] Halat DH, Sarkis DK, Moubareck CA. Carbapenem-Resistant, Gram-Negative Bacilli: The State of the Art. The State of the Art. In: Antibiotic Resistance: Mechanisms and New Antimicrobial Approaches. Elsevier Inc.; 2016. p. 93-119.

[4] Karen C. Carroll M. Pseudomonads, Acinetobacters, and Uncommon Gram-Negative Bacteria. 26th ed. Jawetz, Melnick \& Adelberg's Medical Microbiology. McGraw Hill; 2013. 245 p.

[5] Pang Z, Raudonis R, Glick BR, Lin TJ, Cheng Z. Antibiotic resistance in Pseudomonas aeruginosa: mechanisms and alternative therapeutic strategies. Vol. 37, Biotechnology Advances. Elsevier Inc.; 2019. p. 177-92.

[6] Martínez-Tomé M, Jiménez-Monreal AM, García-Jiménez L, Almela L, García-Diz L, Mariscal-Arcas M, et al. Assessment of antimicrobial activity of coffee brewed in three different ways from different origins. Eur Food Res Technol. 2011;233(3):497-505.

[7] Balouiri M, Sadiki M, Ibnsouda SK. Methods for in vitro evaluating antimicrobial activity: A review. Vol. 6, Journal of Pharmaceutical Analysis. Xi'an Jiaotong University; 2016. p. 71-9.

[8] Wijaya W, Ridwan RD, Budi HS. Antibacterial ability of arabica (Coffea arabica) and robusta (Coffea canephora) coffee extract on Lactobacillus acidophilus. Dent J (Majalah Kedokt Gigi). 2017 Feb 14;49(2):99. 